\title{
Description of the Colonization of a Gnotobiotic Tomato Rhizosphere by Pseudomonas fluorescens Biocontrol Strain WCS365, Using Scanning Electron Microscopy
}

\author{
Thomas F. C. Chin-A-Woeng, Wessel de Priester, Arjan J. van der Bij, and Ben J. J. Lugtenberg \\ Leiden University, Institute of Molecular Plant Sciences, Clusius Laboratory, Wassenaarseweg 64, $2333 \mathrm{AL}$ \\ Leiden, The Netherlands \\ Received 22 August 1996. Accepted 19 October 1996.
}

To study colonization of the tomato root system, we previously have described a gnotobiotic quartz sand system, in which seedlings inoculated with one or two bacterial strains were allowed to grow. Here we present a scanning electron microscope description of the colonization of the tomato root system by Pseudomonas fluorescens biocontrol strain WCS365, with emphasis on spatial-temporal colonization patterns, based on an improved scanning electron microscopy procedure. Upon inoculation of the germinated seed, proliferation on the seed coat was observed for 2 to 3 days. Within 1 to 3 days, micro-colonies developed, mainly at the root base. Most micro-colonies were localized in junctions between epidermal root cells, whereas others were found in indented parts of the epidermal surface. Downward to the root tip, only single bacterial cells were found. Colonization progressed down the root, initially as single cells. A semi-transparent film appeared to enclose the root surface and micro-colonies present on the root. After 7 days, micro-colonies had developed at positions where only single cells were observed previously and distribution of the bacteria along the root varied from $\approx 10^{6}$ CFU per cm of root near the root base to $\approx 10^{2}$ to $10^{3} \mathrm{CFU}$ per $\mathrm{cm}$ of root near the root tip. Similar colonization patterns were found for the $P$. fluorescens biocontrol strains CHAO and F113, and $P$. putida strain WCS358, as well as for four species that have repeatedly been isolated from tomato roots from a commercial tomato field near Granada, Spain. In contrast, four Rhizobium strains and one Acinetobacter radioresistens strain showed poor colonization and micro-colonies were not observed. Based on the described data, we present a model for colonization of the deeper root parts after seed inoculation by $P$. fluorescens biocontrol strains, in which single cells occasionally establish on a deeper root section where they sometimes develop into micro-colonies. We hypothesize that microcolonies are the sites where the intracellular $N$-acyl-Lhomoserine lactone concentration is sufficiently high to cause maximal production of biocontrol factors such as antibiotics and exoenzymes and that micro-colonies ex-

Corresponding author: Ben J. J. Lugtenberg

E-mail: lugtenberg@ rulsfb.LeidenUniv.nl plain the relatively high conjugation frequency observed between pseudomonads in the rhizosphere.

Additional keywords: microbiological control, rhizosphere colonization.

Pathogens, which are responsible for plant diseases and severe crop losses in agriculture, are still mainly repressed by agrochemicals. The pressure to decrease the use of these chemicals has increased attention toward other approaches, including microbiological control, i.e., the use of beneficial microorganisms for protection against harmful organisms (Thomashow and Weller 1995). Two factors are considered to be important for a biological control agent against soilborne pathogens. First, it usually must produce a factor harmful to the pathogen. Second, root colonization is needed to deliver the beneficial bacteria at the right place and the right time on the root. Plant-growth-promoting abilities of microbes have been shown in many field experiments. However, failures and lack of reproducibility have so far discouraged large-scale use of such microbial pesticides (Schroth and Hancock 1981; Schippers et al. 1987a). Root colonization often is the limiting step in the use of rhizobacteria as biocontrol agents (Schippers et al. 1987b; Weller 1988) and therefore a clear understanding of the colonization process is required to be able to screen or develop strains possessing good biocontrol activity under a variety of field conditions. We recently described a gnotobiotic system to analyze rhizosphere colonization after inoculation of germinated seeds with cells of one or two Pseudomonas biocontrol strains, with the aim of using this system (i) to screen and test individual random transposon mutants for their ability to colonize the root, and (ii) to analyze the influence of individual biotic or abiotic factors on colonization (Simons et al. 1996).

In the present paper we describe the analysis of the colonization process in more detail, with scanning electron microscopy (SEM). We describe the spatial-temporal tomato rhizosphere colonization pattern of $P$. fluorescens strain WCS365, a good colonizer of the rhizospheres of tomato, potato, and wheat. SEM fills the gap in resolving power between light microscopy and transmission electron microscopy and allows exact localization of microorganisms in relation to the 
surface architecture of the root (Campbell and Rovira 1973; Rovira and Campbell 1975). This cannot be accomplished with other detection methods such as plating techniques and reporter genes.

\section{RESULTS}

\section{Comparison of fixation methods.}

After removal of the plantlets from the colonization tubes, samples were immediately fixed to prevent changes in bacterial distribution. Classical fixation of the delicate tomato root sections with $2.5 \%$ glutaraldehyde and postfixation with $\mathrm{OsO}_{4}$ resulted in heavy distortion of the samples. Bacteria localized in deeper parts of the root surface (e.g., in junctions between epidermal cells) were difficult to visualize with this standard method. Introduction of an additional treatment, using $\mathrm{OsO}_{4}$ cross-linked with $\mathrm{TCH}$, resulted in an improved overall preservation of roots and bacteria. To improve conductivity of the specimen and to obtain a gold secondary signal, coating with only a very thin gold layer was adequate. At lower acceleration voltages $(5 \mathrm{kV})$, observations without a gold layer were feasible. However, coating with a gold layer enhanced the quality of the image. In both standard and TCH-treated samples, a film appeared to cover the entire root surface; in contrast to the situation in standard samples, this film appeared as semi-transparent in TCH-treated samples. Standard samples required a much thicker gold layer, and bacteria under the semi-transparent film were extremely difficult to detect. We therefore chose to use the $\mathrm{TCH}$ treatment and coating with a thin gold layer. A total view on the root epidermis was only possible when blocking sand particles and root hairs were moved aside before coating.

\section{Distribution of cells of $P$. fluorescens strain WCS365 in the tomato rhizosphere based on dilution plating and immunofluorescence microscopy.}

As measured 3 and 7 days after inoculation, both dilution plating (Table 1) and immunofluorescence microscopy of 10$\mathrm{mm}$-long primary root sections showed that the number of

Table 1. Bacterial numbers on primary roots of tomato

\begin{tabular}{lcc}
\hline Day $($ mean root length) & $\begin{array}{c}\text { Distance from root } \\
\text { base }(\mathbf{c m})\end{array}$ & log $(\mathbf{C F U}) / \mathbf{c m} \pm \mathbf{S D}$ \\
\hline Day $3(6.8 \mathrm{~cm}, \mathrm{n}=6)$ & 0 to 1 & $6.0 \pm 0.4$ \\
1 to 2 & $5.4 \pm 0.3$ \\
2 to 3 & $4.5 \pm 0.9$ \\
3 to 4 & $4.2 \pm 0.9$ \\
4 to 5 & $3.3 \pm 0.7$ \\
5 to 6 & $2.6 \pm 0.6$ \\
& 6 to 7 & $2.0 \pm 0.5$ \\
Day $7(11.6 \mathrm{~cm}, \mathrm{n}=4)$ & 0 to 1 & $6.5 \pm 0.2$ \\
& 1 to 2 & $5.8 \pm 0.2$ \\
& 2 to 3 & $5.3 \pm 0.3$ \\
& 3 to 4 & $5.0 \pm 0.2$ \\
4 to 5 & $5.0 \pm 0.1$ \\
5 to 6 & $4.8 \pm 0.2$ \\
6 to 7 & $4.5 \pm 0.3$ \\
& 7 to 8 & $4.2 \pm 0.3$ \\
& 8 to 9 & $4.0 \pm 1.0$ \\
9 to 10 & $3.8 \pm 0.4$ \\
10 to 11 & $3.7 \pm 0.3$ \\
\hline
\end{tabular}

\footnotetext{
${ }^{a}$ Mean and SD were calculated from $\log _{10}(\mathrm{CFU} / \mathrm{cm})$ values obtained by
} dilution plating of the indicated root sections. bacteria rapidly decreased in the direction of the root tip. The distribution of bacteria between the rhizoplane and the attached rhizosphere sand was determined after separate dilution plating of rhizosphere sand, which was removed with sterile forceps, and the remaining sand-free 10-mm-long root sections. Data indicated that at the proximal part of the root, the number of bacteria on the rhizoplane at $2 \mathrm{~cm}$ below the root base $\left(\approx 10^{5} \mathrm{CFU}\right.$ per $\mathrm{cm}$ of root) was approximately two orders of magnitude higher than the number in rhizosphere sand $\left(\approx 10^{3} \mathrm{CFU}\right.$ per $\mathrm{cm}$ of root). For more distal parts of the root, at $2 \mathrm{~cm}$ above the root tip, the difference was approximately 10 -fold $\left(\approx 10^{3} \mathrm{CFU} / \mathrm{cm}\right.$ and $\approx 10^{2} \mathrm{CFU} / \mathrm{cm}$, respectively).

Immunofluorescence microscopy of root sections colonized by strain WCS365 gave a clearer overview on the distribution of colonies on the root epidermis (data not shown). The observations agree with the results from SEM.

\section{Spatial-temporal distribution and organization of bacteria along the root system based on SEM observations.}

During the 14-day period in which colonization was followed by SEM, most bacteria were found on the root epidermis. Observations of the remaining rhizosphere sand grains and root hairs showed that no bacteria were present on the root hairs and only a few bacteria attached to the sand particles. Furthermore, the entire root surface and nearly all bacteria were enclosed in a matrix or covered by a semi-transparent film (Fig. 1), which was absent from the seed coat. Bacteria contacted the root epidermis directly at their lateral sides.

Three hours after inoculation of germinated seeds, single bacterial cells were detected on the seed coat as well as on the root surface. Approximately $24 \mathrm{~h}$ after inoculation, the tomato

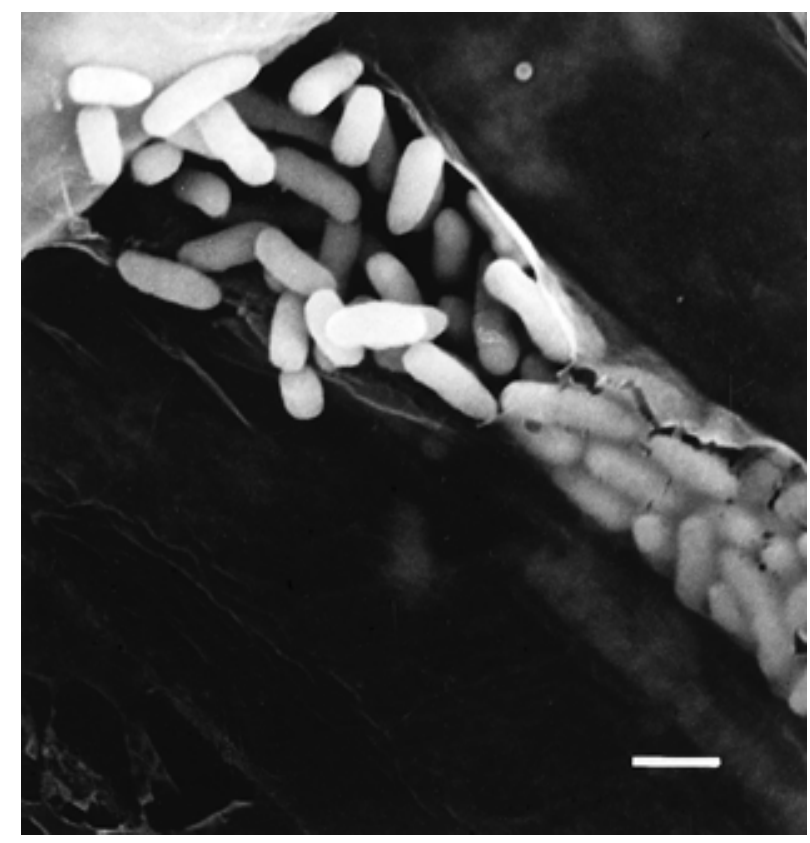

Fig. 1. Part of a micro-colony of Pseudomonas fluorescens strain WCS365 on the tomato root epidermis, approximately $3 \mathrm{~cm}$ from the root base, 4 days after inoculation. The micro-colony is aligned along the junction between root epidermal cells. A disruption in the semitransparent layer is clearly visible at one end of the micro-colony. The bar represents $1 \mu \mathrm{m}$. 
roots were between 10 and $15 \mathrm{~mm}$ in length. Bacteria on the seed coat as well as on the root base had started to proliferate. In some cases, small micro-colonies were observed on the proximal part of the root.

During the first 3 days after inoculation, strong proliferation of bacteria was observed on the seed coat. This coincided with the period during which the seed had not yet emerged from the sand. Both direct counts from SEM images and dilution plating showed that the number of bacteria on the seed coat increased from $5 \cdot 10^{2}$ cells $/ \mathrm{mm}^{2} 1 \mathrm{~h}$ after inoculation (Fig. 2A) to $5 \cdot 10^{4}$ cells $/ \mathrm{mm}^{2}$ after approximately 3 days (Fig. 2B). Later on, the bacteria disappeared from the seed coat. During this whole period, single cells, but no micro-colonies, were observed on the seed (Fig. 2B).

After 3 days, the roots were approximately $7 \mathrm{~cm}$ long. The highest bacterial numbers were always found near the root base. A remarkable change in number was noticed at the morphological boundary between stem and root: no bacteria were detected on the stem, whereas the root section directly under the stem was covered with bacteria (Fig. 3). On the proximal part of the root epidermis most bacteria were organized in micro-colonies, whereas, farther down, areas with micro-colonies gradually were replaced by areas where only single cells were observed. Near the root apex only single bacteria were found. Most micro-colonies and individual cells were located in the junctions between epidermis cells or in deeper parts of the root epidermis. Some micro-colonies were also found at the indented surface of epidermal cells. Most micro-colonies consisted of multiple layers of bacteria. Bacterial cells were

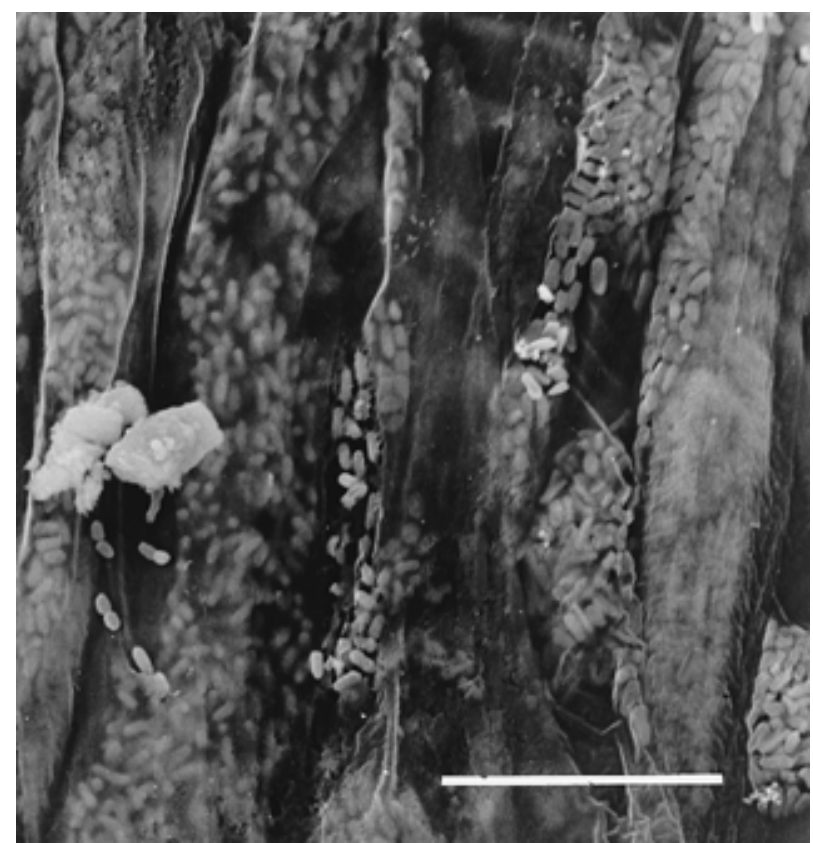

Fig. 3. Root epidermis of a tomato seedling 3 days after inoculation This region, located approximately $1 \mathrm{~cm}$ under the stem, is covered by Pseudomonas fluorescens strain WCS365. Numbers declined drastically down the root. Most bacteria are clearly covered by a mucigel (semitransparent) layer. The bar represents $10 \mu \mathrm{m}$.
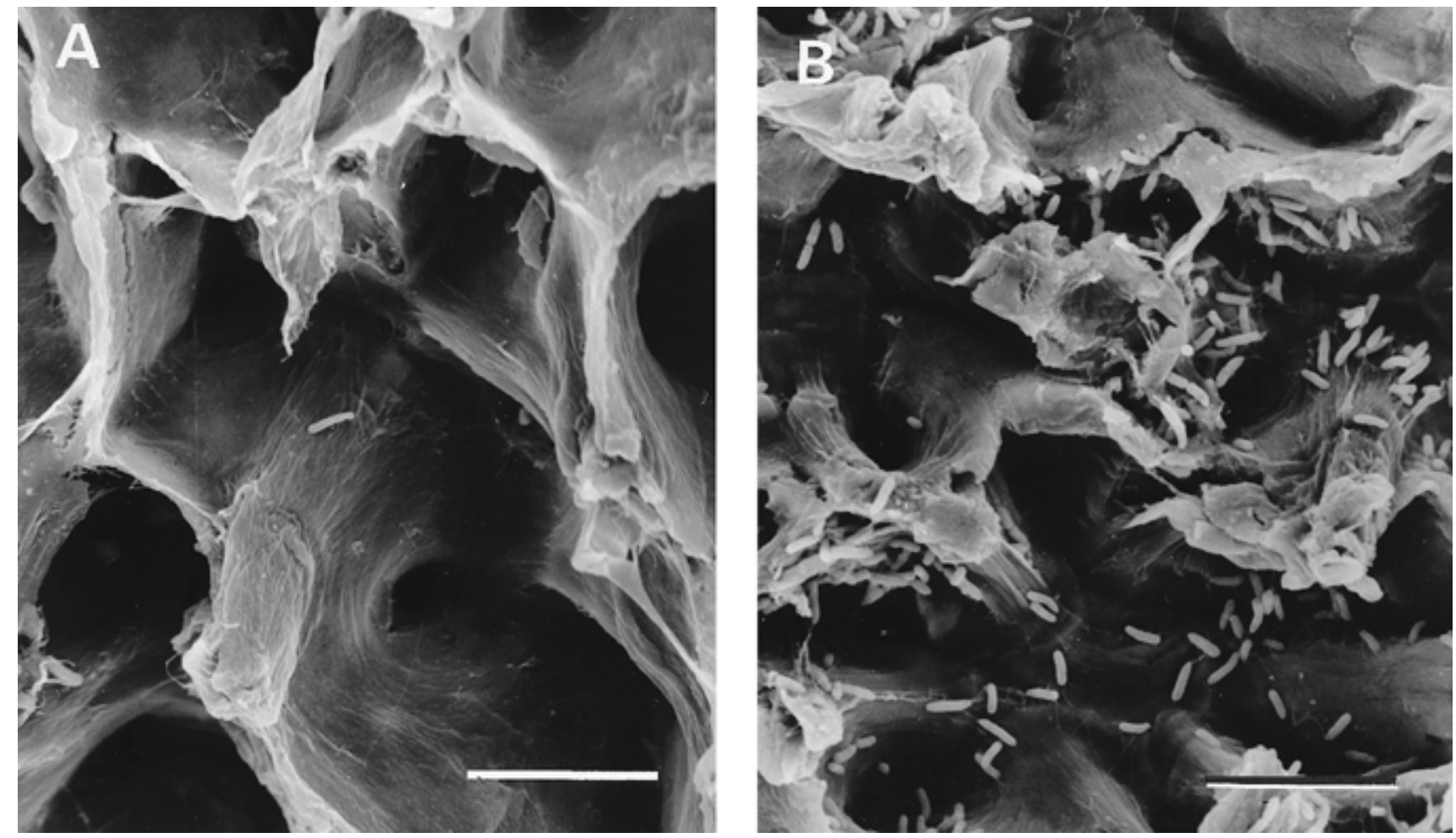

Fig. 2. Seed coat of tomato seedling cv. Carmello in (A) the first hour and (B) $48 \mathrm{~h}$ after inoculation of the seedling with cells of $P$. fluorescens WCS365. Bacterial numbers on the seed coat determined by dilution plating and scanning electron microscopy yielded similar results, namely, $5 \cdot 10^{2}$ cells $/ \mathrm{mm}^{2}$ and $5 \cdot 10^{4}$ cells $/ \mathrm{mm}^{2}$ directly after inoculation and 2 days later, respectively. Only single cells and no micro-colonies are present. The bar represents 10 $\mu \mathrm{m}$. 
either aligned along junctions between epidermal cells and had an elongated shape (Fig. 4), or they formed a small protrusion on the root epidermis. Micro-colonies were randomly distributed along the epidermis with some areas in which micro-colonies were lacking and other regions in which several micro-colonies were present within a $10-\mu \mathrm{m}$ radius.

Seven days after inoculation the primary roots were approximately $12 \mathrm{~cm}$ long. Short lateral roots had been formed on the proximal part of the root. Bacterial distribution on these lateral roots was similar to that on the primary root. Dilution plating showed that the number of bacteria just below the inoculation site had reached a density between $10^{6}$ to $10^{7} \mathrm{CFU}$ per $\mathrm{cm}$ of root. The small micro-colonies, observed on the root after 3 days, seemed to have expanded during the next days of the colonization process (Fig. 5). These long-shaped microcolonies could reach a length of up to $200 \mu \mathrm{m}$ and were estimated to consist of up to several hundreds to thousands of cells. At more distal sites, where initially only single cells were observed, micro-colonies appeared after prolonged incubation.

After 14 days, bacterial numbers on the upper part of the root system hardly had increased, whereas lower parts of the root had become more densely colonized by both single bacteria and micro-colonies.

\section{Colonization by other rhizosphere bacteria.}

To determine the colonization patterns of other rhizosphere bacteria, colonization assays were carried out with the $P$. fluorescens biocontrol strains CHA0 and F113, with $P$. putida biocontrol strain WCS358, with Rhizobium strains 248, LPR5020, ANU843 and 1021, and with species isolated from tomato rhizospheres from a commercial tomato field in Spain, namely, $P$. mendocina, Acidovorax facilis, Acinetobacter radioresistens, and Xanthomonas oryzae (Table 2). Seven days after inoculation, the colonization patterns of the Pseudomonas biocontrol strains and those of P. mendocina, Acidovorax facilis, and Xanthomonas oryzae, as analyzed by SEM, were indistinguishable from the pattern observed for $P$. fluo- rescens strain WCS365. The distributions of bacteria along the root system were similar to that of strain WCS365, and micro-colonies were mainly observed in the grooves between epidermal cells. With the use of SEM, Acinetobacter radioresistens appeared to be a poor colonizer of the tomato rhizosphere and no micro-colonies were observed for this strain. Dilution plating indicated that this strain colonized the root to a 100-fold lesser extent than P. fluorescens strain WCS365.

The four Rhizobium strains colonized the entire tomato root system, but to a 10- to 100-fold lesser extent. Micro-colonies were not observed, even not on 7-day-old roots. Along the whole root system, Rhizobium bacteria were present as single cells, both on the epidermis and root hairs. These cells were randomly distributed over the epidermal surface, without the preference for grooves between epidermal cells that was shown by the Pseudomonas strains. Experiments in which $R$. leguminosarum strain 248 was inoculated on its host plant $V i$ cia sativa $\mathrm{L}$. showed that, in addition to the pattern observed on tomato, the bacteria that were present on the root hairs showed the cap formation (not shown) characteristic for the attachment of cells of this strain to pea, and other host plants of R. leguminosarum strain 248 (Smit et al. 1989).

\section{DISCUSSION}

In order to prevent deformation of the delicate tomato root sections during the preparation for the SEM, we introduced a $\mathrm{TCH}$ treatment, by which osmium is cross-linked, after the standard fixation procedure. This new method appeared to have the additional advantage of allowing the samples to be examined without or with only a thin layer of gold, thereby revealing details, such as bacteria under a film, that would be obscured by a thicker gold layer as applied in the standard procedure.

In both the standard and TCH-treated samples, the entire root surface was covered by a film. This film also covered bacteria present on the root surface in the standard procedure but appeared semi-transparent in the modified procedure. The

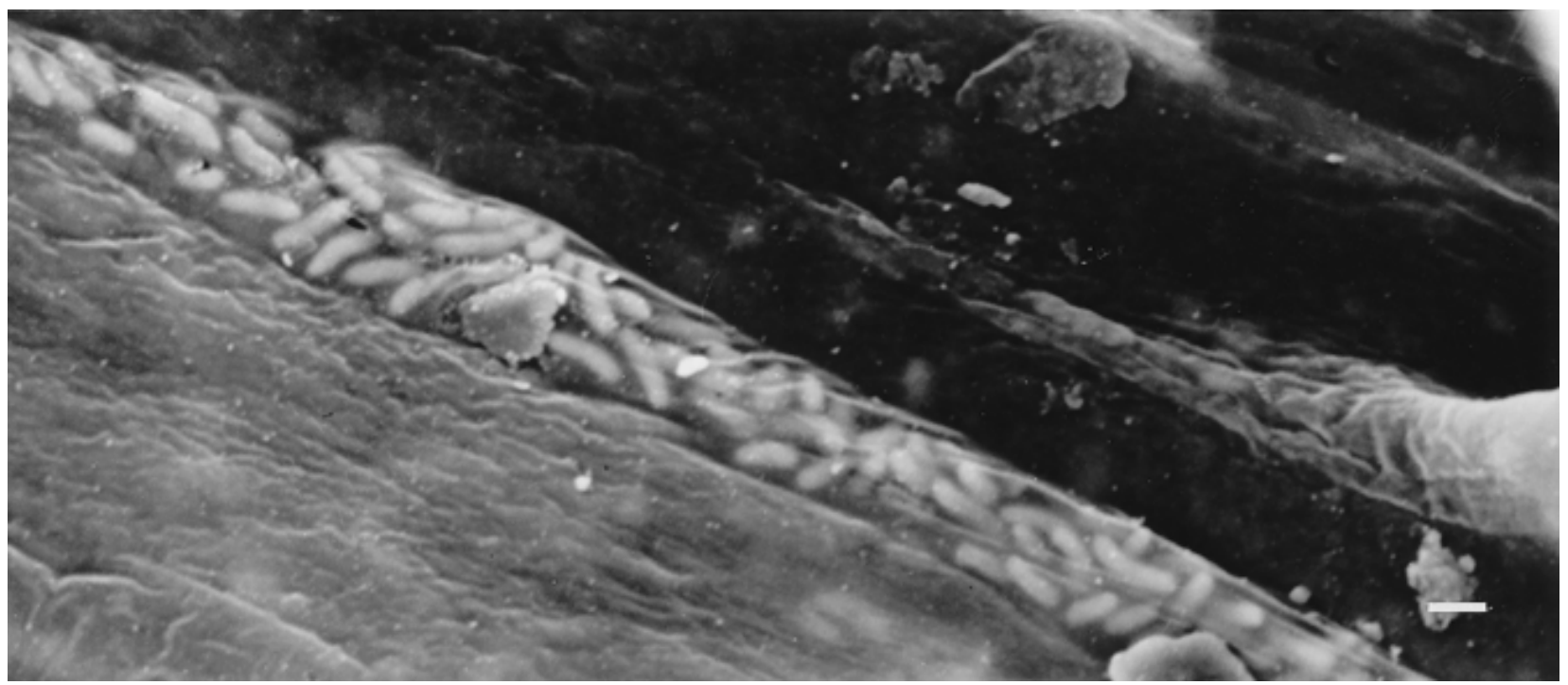

Fig. 4. Part of a long-stretched micro-colony of Pseudomonas fluorescens strain WCS365 on the epidermis of a 3-day-old tomato root, approximately 3 $\mathrm{cm}$ below the root base. The colony is aligned along the junction between epidermal cells. The bar represents $1 \mu \mathrm{m}$. 
presence of the film can easily be noted as it is damaged at some places along the root (Fig. 1). Since the substance on the root surface is also present when bacteria are absent, it must be produced by the root. Earlier electron microscopical studies showed that plant roots and bacteria on the root epidermis are often enclosed by a distinct matrix or layer, the mucigel (Jenny and Grossenbacher 1963), and bacteria were not observed until this layer was disrupted during preparation for electron microscopy (Foster and Rovira 1976; Foster 1981; Foster 1982). Apparently, this problem is overcome by the modification that we introduced in the procedure. We assume that the mucigel is reduced in thickness due to the dehydration steps in the protocol for the preparation of our samples to appear as the thin film covering the root surface and bacteria (Fig. 1). The semi-transparency of the film is probably caused by the generation of secondary electrons from both the thin gold layer and the underlying layers in which $\mathrm{OsO}_{4}$ has penetrated. The structure of the mucigel visualized with SEM depends strongly upon the plant species and the preparation methods used. Even washing of roots prior to fixation, or inadequate staining, can eliminate detection of parts of this structure (Foster 1982).

The most important aspects of the spatial-temporal behavior of $P$. fluorescens strain WCS365 on the tomato root are (i) the increased number of individual cells in time and on new root areas, and (ii) the increased number of micro-colonies, mainly in the junctions between epidermal cells and at the root base, in time and on new root areas. These sites and patterns of colonization by rhizosphere bacteria have also been shown earlier (Rovira 1956; Newman and Bowen 1974). For rhizobia the number of individual cells also increases, although to a 10to 100-fold lesser extent than for strain WCS365. However, micro-colonies were not formed. These observations are consistent with the following model of root colonization for strain WCS365. (i) Upon inoculation, the cells proliferate on the seed coat, mainly using nutrients provided by the seed coat and/or seed exudate. (ii) Individual cells colonize the root base and later gradually appear on lower parts of the root. The ob- servation that sand particles are hardly colonized suggests a mechanism in which chemotaxis toward components on lower parts of the root and/or attachment to plant root compounds play a role (Hiltner 1904). (iii) At specific sites, often corresponding with junctions between epidermal cells, one or a few individual cells proliferate into micro-colonies. The formation of micro-colonies at these specific sites likely reflects the availability of nutrients on the root surface. In this respect it is worthwhile mentioning that junctions between epidermal cells have been proposed to be leaky for root exudates (Campbell and Greaves 1990).

We have two possible explanations for the observation that rhizobia do not form micro-colonies on tomato roots. First, rhizobia grow too slowly under these circumstances to reach micro-colony density within the period of observation. Second, the exudate proposed to be required for growth of pseudomonads, and hence micro-colony formation, may not be suitable for, or even inhibit, growth of rhizobia.

Root hairs seem to behave differently from other parts of the root with respect to their interaction with bacteria. Tomato root hairs are not colonized by pseudomonads whereas they are colonized by all tested rhizobia. On tomato, cap formation, i.e., aggregation of bacteria on the tip of the root hair, as described for the interaction between $R$. leguminosarum bv. viciae and its host plant pea (Smit et al. 1989), was not observed. With the use of SEM, we confirmed cap formation of $R$. leguminosarum strain 248 on pea root hair tips (results not shown).

Studies on plasmid transfer frequencies in soil demonstrated that conjugation between pseudomonads in soil is significantly and unexpectedly stimulated in the 0 - to 1-mm layer adjacent to the plant root (van Elsas et al. 1988). Since we have observed that pseudomonads form micro-colonies on the root (this paper) and since it is known that $N$-acyl-Lhomoserine lactones can play a role in conjugation (Zhang et al. 1993), we assume that the observed conjugation frequency is caused by a combination of the high cell density in microcolonies-and therefore increased chances of cell-to-cell

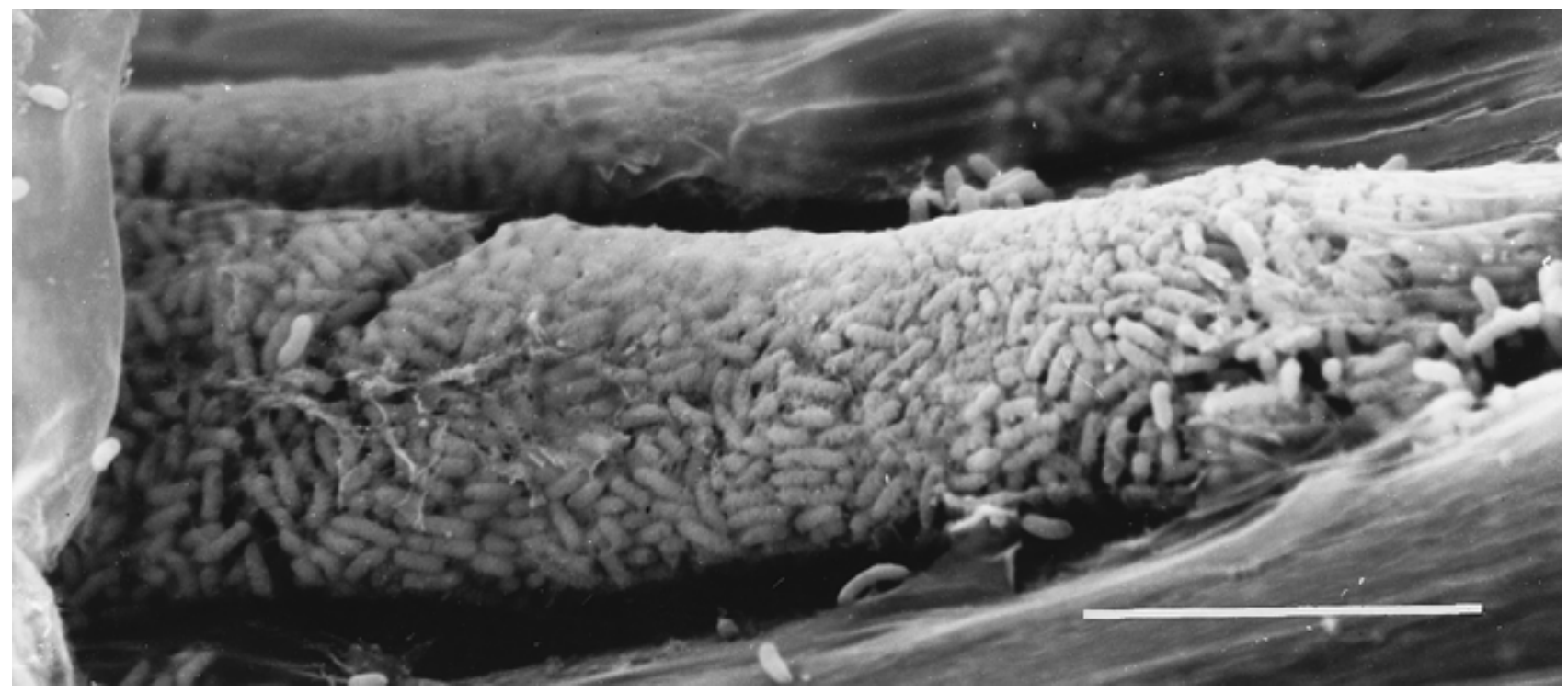

Fig. 5. Micro-colony of Pseudomonas fluorescens strain WCS365 on the tomato root epidermis, approximately 3 cm below the root base, 7 days after inoculation. Comparison with Figure 4 shows the increase of size and thickness of the micro-colonies with time. The bar represents $10 \mu \mathrm{m}$. 
contact-and increased conjugation frequency due to the production of $\mathrm{N}$-acyl-L-homoserine lactones in the microcolonies.

Many biocontrol bacteria exert their antifungal action through the production of antibiotics and/or extracellular enzymes. For example, the production of 2,4-diacetylphloroglucinol and monoacetylphloroglucinol by $P$. fluorescens biocontrol strains CHA0 and F113 is associated with suppression of black root rot of tobacco caused by Thielaviopsis basicola (Keel et al. 1992) and protection of sugar beet against Pythium ultimum (Shanahan et al. 1992), respectively. The phenazineproducing strains $P$. fluorescens 2-79 and P. aureofaciens 3084 suppress take-all of wheat and barley, caused by Gaeumannomyces graminis var. tritici (Thomashow and Weller 1988; Pierson III and Thomashow 1992). It is now recognized that environmental-sensing mechanisms modulate the production of many antifungal factors, among which are phenazines, phloroglucinols, hydrogen cyanide, chitinases, and proteases. The gacA/ lemA gene pair, encoding a sensor kinase and global response regulator, respectively, have been found to regulate the production of antibiotics, cyanide, proteases, tryptophan side-chain oxidase, and phospholipase C (Laville et al. 1992; Sacherer et al. 1994). The environmental signal for the sensor kinase has not been identified yet. The phenazine synthesis regulator genes $p h z I$ and $p h z R$, encoding an autoinducer synthase and response regulator (Pierson III et al. 1994; Cook et al. 1995), respectively, are involved in the regulation of gene expression in response to a diffusable, acylated, homoserine lactone derivative when its intracellular concentration exceeds a certain threshold value (Salmond et al. 1995). Micro-colonies embedded in a mucigel (Fig. 1), as well as the sites with high bacterial densities on the root base (Fig. 3), therefore seem to us ideal locations for the intracellular accumulation of $\mathrm{N}$-acyl-L-homoserine lactone, and consequently for antibiotic production and biocontrol. Since the sites with high bacterial densities, as well as the sites where micro-colonies are present, are among the most vulnerable sites for attack by fungi, we suggest that the formation of micro-colonies is a crucial step in biocontrol by pseudomonads.

\section{MATERIALS AND METHODS}

\section{Bacterial strains.}

Bacterial strains and their relevant characteristics are listed in Table 2. Pseudomonas strains were routinely grown in liquid King's medium B (KB) (King et al. 1954). Rhizobium strains were grown in TY medium (Beringer 1974). Tomato (Lycopersicon esculentum Mill.) rhizosphere isolates from a commercial tomato field near Granada, Spain, and typed with the Biolog system (Biolog, Inc., Hayward, CA) (Bochner 1989), were grown in Luria-Bertani (LB) medium (Sambrook et al. 1989). All strains were grown under aeration at $28^{\circ} \mathrm{C}$.

\section{Colonization assay.}

The gnotobiotic system has been described in detail (Simons et al. 1996). Briefly, tomato (Lycopersicon esculentum Mill.) seeds (cv. Carmello) provided by S\&G Seeds, Enkhuizen, The Netherlands, were surface sterilized by soaking in a $5 \%$ household sodium hypochlorite solution for $3 \mathrm{~min}$, followed by four thorough rinses with sterile water for $2 \mathrm{~h}$. Incubation of sterilized tomato seeds on $\mathrm{KB}$, solidified with $1.8 \%$ (wt/vol) agar (Difco Laboratories, Detroit, MI), showed that this method consistently yielded seeds free of contamination. After incubating for $24 \mathrm{~h}$ on agar-solidified plant nutrient solution (PNS) medium (Hoffland et al. 1989) at $4^{\circ} \mathrm{C}$, seeds were allowed to germinate at $28^{\circ} \mathrm{C}$. Seedlings were inoculated 2 days later. We chose this method of inoculation instead of inoculation from soil since (i) commercial biocontrol of tomato pathogens is based on seed coating and (ii) plants grown from germinated seeds behave more reproducibly than those grown from seeds. An overnight, stationary phase culture of bacteria in $\mathrm{KB}$ or LB medium was centrifuged, the cell pellet

Table 2. Strains used and their characteristics

\begin{tabular}{|c|c|c|}
\hline Strain & Characteristics & Reference \\
\hline \multicolumn{3}{|l|}{ Pseudomonas fluorescens } \\
\hline WCS365 & Efficient colonizer, biocontrol strain & Simons et al. 1996; Geels and Schippers 1983 \\
\hline CHA0 & $\begin{array}{l}\text { Biocontrol strain, produces 2,4-diacetyl-phloro gluci- } \\
\text { nol, monoacetylphloroglucinol, hydrogen cyanide, } \\
\text { pyoluteorin, salicylic acid, indole-3-acetic acid }\end{array}$ & Défago et al. 1990; Oberhänsli et al. 1991 \\
\hline F113 & Biocontrol strain, produces 2,4-diacetylphloroglucinol & Shanahan et al. 1992 \\
\hline \multicolumn{3}{|l|}{ Pseudomonas putida } \\
\hline WCS358 & $\begin{array}{l}\text { Biocontrol strain, siderophore producer; possesses } \\
\text { multiple siderophore-uptake systems enabling this } \\
\text { strain to use heterologous siderophores }\end{array}$ & Koster et al. 1993; Leeman et al. 1995 \\
\hline \multicolumn{3}{|l|}{ Rhizobium } \\
\hline R. leguminosarum 248 & Wild-type biovar viciae strain & Josey et al. 1979 \\
\hline R. leguminosarum LPR5020 & Wild-type biovar trifolii strain & Hooykaas et al. 1981 \\
\hline R. leguminosarum ANU843 & Wild-type biovar trifolii strain & Rolfe et al. 1980 \\
\hline R. meliloti 1021 & Wild-type biovar meliloti strain & Meade et al. 1982 \\
\hline \multicolumn{3}{|l|}{ Tomato rhizosphere isolates } \\
\hline Pseudomonas mendocina & Isolated from the tomato rhizosphere & $\begin{array}{l}\text { L. A. de Weger, A. J. van der Bij, F. de Rooij, R. Scheffer, } \\
\text { H. V. Tichy, R. Simon, J. Olivares, and B. J. J. Lugtenberg }\end{array}$ \\
\hline Acidovorax facilis & Isolated from the tomato rhizosphere & $\begin{array}{l}\text { L. A. de Weger, A. J. van der Bij, F. de Rooij, R. Scheffer, } \\
\text { H. V. Tichy, R. Simon, J. Olivares, and B. J. J. Lugtenberg }\end{array}$ \\
\hline Xanthomonas oryzae & Isolated from the tomato rhizosphere & $\begin{array}{l}\text { L. A. de Weger, A. J. van der Bij, F. de Rooij, R. Scheffer, } \\
\text { H. V. Tichy, R. Simon, J. Olivares, and B. J. J. Lugtenberg }\end{array}$ \\
\hline Acinetobacter radioresistens & Isolated from the tomato rhizosphere & $\begin{array}{l}\text { L. A. de Weger, A. J. van der Bij, F. de Rooij, R. Scheffer, } \\
\text { H. V. Tichy, R. Simon, J. Olivares, and B. J. J. Lugtenberg }\end{array}$ \\
\hline
\end{tabular}


washed in PNS, and diluted in PNS to a final concentration of $10^{8} \mathrm{CFU} / \mathrm{ml}$. Germinated seeds were incubated in this suspension of bacteria for $15 \mathrm{~min}$ and planted in tubes filled with quartz sand (Simons et al. 1996). Plants were incubated for 1, $2,3,7$, and 14 days in a growth chamber at $19^{\circ} \mathrm{C}(16 / 8 \mathrm{~h}$ day/night cycles, $70 \%$ humidity). For each experiment, at least three independent colonization assays were carried out, and three roots were sectioned and prepared for observations. The distribution of bacteria along the root system was also determined by shaking 10-mm root sections in $1.0 \mathrm{ml}$ of PNS for 15 min on an Eppendorf shaker, followed by dilution plating on agar medium with a Spiral Plater (Spiral Systems, Inc., Cincinnati, $\mathrm{OH}$ )

For immunofluorescence microscopy, plantlets were removed from the colonization tubes and the roots were cut in $1-\mathrm{cm}$ pieces, fixed with $2 \%$ (wt/vol) paraformaldehyde in PNS for $2 \mathrm{~h}$, washed with PNS, and incubated for $15 \mathrm{~min}$ in buffer (20 mM Tris, $0.9 \% \mathrm{NaCl}, 0.1 \%$ bovine serum albumin [BSA], $0.02 \%$ fish skin gelatin, $\mathrm{pH} 8.2$ ). Incubation was done in rabbit antiserum raised against cell surface components of WCS365 in BSA buffer, followed by washes in BSA buffer, and incubated for $2 \mathrm{~h}$ with a horse anti-rabbit tetramethylrhodamine-isothyocyanate (TRITC) conjugate. Samples were mounted on microscope slides for observation with a fluorescence microscope. Fluorescent signal in negative controls, consisting of incubation with the second antibody only, was not above the basal autofluorescence of the root.

\section{Preparation of roots for SEM and observations.}

Plantlets were gently removed from the tubes, and the roots, covered with a monolayer of sand grains, were sectioned into $1.5-$ to $2-\mathrm{cm}$ pieces. For standard fixation, these root sections were fixed for $2 \mathrm{~h}$ at room temperature in glutaraldehyde $(2.5 \% \mathrm{wt} / \mathrm{vol}$ in $50 \mathrm{mM}$ phosphate buffer, $\mathrm{pH} 7.2)$ and rinsed in phosphate buffer. After postfixation with $1.0 \%$ osmiumtetroxide $\left(\mathrm{OsO}_{4}\right)$ in water for $1 \mathrm{~h}$, two additional osmication steps were introduced by cross-linking with a saturated $1 \%$ solution of thiocarbohydrazide (TCH) (Merck, Darmstadt, Germany) (Malick and Wilson 1975). Samples were dehydrated by a series of acetone rinses (30 to $100 \%$ ), subjected to critical point drying and mounted on metal stubs $(2 \mathrm{~cm}$ diameter) with double-sided adhesive tape. Sand particles and root hairs blocking a clear view to the root epidermis were moved aside or removed with forceps. After being coated with a thin gold layer, with a SEM coating unit E5100 (Polaron Equipment Ltd., Watford, U.K.), the samples were directly examined in a JSM6400 scanning electron microscope (JEOL, Tokyo, Japan) operating at $5 \mathrm{kV}$ or at $12 \mathrm{kV}$. Magnifications of up to $\times 5,000$ were used for microscopic observations.

\section{ACKNOWLEDGMENTS}

We wish to thank Johan E. Pinas and Gerda E. M. Lamers from the institute's electron microscopy unit for technical assistance during the preparation and observations of samples for SEM, and Marco Simons and Carel A. Wijffelman for valuable discussions and critical reading of the manuscript. We thank Letty A. de Weger for providing the antibody directed against $P$. fluorescens strain WCS365.

\section{LITERATURE CITED}

Beringer, J. E. 1974. R factor transfer in Rhizobium leguminosarum. J. Gen. Microbiol. 84:188-198.
Bochner, B. R. 1989. Sleuthing out bacterial identities. Nature 339:157158.

Campbell, R., and Greaves, M. P. 1990. Anatomy and community structure of the rhizosphere. Pages 11-34 in: The Rhizosphere. J. M. Lynch, ed. John Wiley \& Sons, West Sussex, England.

Campbell, R., and Rovira, A. D. 1973. The study of the rhizosphere by scanning electron microscopy. Soil Biol. Biochem. 5:747-752.

Cook, R. J., Thomashow, L. S., Weller, D. M., Fujimoto, D., Mazzola, M., Bangera, G., and Kim, D.-s. 1995. Molecular mechanisms of defense by rhizobacteria against root disease. Proc. Natl. Acad. Sci. USA 92:4197-4201.

Défago, G., Berling, C. H., Burger, U., Haas, D., Kahr, G., Keel, C., Voisard, C., Wirthner, P., and Wüthrich, B. 1990. Suppression of black rot of tobacco and other diseases by strains of Pseudomonas fluorescens. Potential applications and mechanisms. Pages 93-108 in: Biological Control of Soil Borne Pathogens. D. Hornby, R. J. Cook, Y. Henis, W. H. Ko, B. Schippers, and P. R. Scott, eds. CAB International, Wallingford, England.

Foster, R. C. 1981. The ultrastructure and histochemistry of the rhizosphere. New Phytol. 89:263-273.

Foster, R. C. 1982. The fine structure of epidermal cell mucilages of roots. New Phytol. 91:727-740.

Foster, R. C., and Rovira, A. D. 1976. Ultrastructure of wheat rhizosphere. New Phytol. 76:343-352.

Geels, F. P., and Schippers, G. 1983. Selection of antagonistic fluorescent Pseudomonas spp. and their root colonization and persistence following treatment of seed potatoes. Phytopathol. Z. 108:193-206.

Hiltner, L. 1904. Uber neue Erfahrungen und Probleme auf dem Gebiete der Bodenbakteriologie. Arb. Dtsch. Landwirtsch. Ges., Berlin 98:5978.

Hoffland, E., Findenegg, G. R., and Nelemans, J. A. 1989. Solubilization of rock phosphate by rape. Plant Soil 113:161-165.

Hooykaas, P. J. J., van Brussel, A. A. N., den Dulk-Ras, H., Slogteren, G. M. S., and Schilperoort, R. A. 1981. Sym-plasmid of Rhizobium trifolii expressed in different Rhizobial species and Agrobacterium tumefaciens. Nature 291:351-353.

Jenny, H., and Grossenbacher, K. 1963. Root-soil boundary zones as seen in the electron microscope. Soil Sci. Soc. Am. Proc. 27:273-277.

Josey, D. P., Beynon, J. L., Johnston, A. W. B., and Beringer, J. E. 1979. Strain identification in Rhizobium using intrinsic antibiotic resistance. J. Appl. Bacteriol. 46:343-350.

Keel, C., Schnider, U., Maurhofer, M., Voisard, C., Laville, J., Burger, U., Wirthner, P., Haas, D., and Défago, G. 1992. Suppression of root diseases by Pseudomonas fluorescens CHA0: Importance of the bacterial secondary metabolite 2,4-diacetylphloroglucinol. Mol. PlantMicrobe Interact. 5:4-13.

King, E. O., Ward, M. K., and Raney, D. E. 1954. Two simple media for the demonstration of pyocyanin and fluorescein. J. Lab. Clin. Med. 44:301-307.

Koster, M., van de Vossenberg, J., Leong, J., and Weisbeek, P. J. 1993. Identification and characterization of the $p u p B$ gene encoding an inducible ferric-pseudobactin receptor of Pseudomonas putida WCS358. Mol. Microbiol. 8:591-601.

Laville, J., Voisard, C., Keel, C., Maurhofer, M., Défago, G., and Haas, D. 1992. Global control in Pseudomonas fluorescens mediating antibiotic synthesis and suppression of black root rot of tobacco. Proc. Natl. Acad. Sci. USA 89:1562-1566.

Leeman, M., Van Pelt, J. A., Den Ouden, F. M., Heinsbroek, M., Bakker, P. A. H. M., and Schippers, B. 1995. Induction of systemic resistance against Fusarium wilt of radish by lipopolysaccharides of Pseudomonas fluorescens. Phytopathology 85:1021-1027.

Malick, L. E., and Wilson, R. B. 1975. Modified thiocarbohydrazide procedure for scanning electron microscopy: routine use for normal, pathological, or experimental tissues. Stain Technol. 50:265-269.

Meade, H. M., Long, S. R., Ruvkum, G. B., Brown, S. E., and Ausubel, F. M. 1982. Physical and genetic characterization of symbiotic and auxotrophic mutants of Rhizobium meliloti induced by transposon Tn5 mutagenesis. J. Bacteriol. 149:114-122.

Newman, E. I., and Bowen, H. J. 1974. Patterns of distribution of bacteria on root surfaces. Soil Biol. Biochem. 6:205-209.

Oberhänsli, T., Défago, G., and Haas, D. 1991. Indole-3-acetic acid (IAA) synthesis in the biocontrol stran CHA0 of Pseudomonas fluorescens: role of tryptophan side chain oxidase. J. Gen. Microbiol. 137: 2273-2279. 
Pierson, L. S., III, Keppenne, V. D., and Wood, D. W. 1994. Phenazine antibiotic biosynthesis in Pseudomonas aureofaciens 30-84 is regulated by PhzR in response to cell density. J. Bacteriol. 176:3966-3974.

Pierson, L. S., III, and Thomashow, L. S. 1992. Cloning and heterologous expression of the phenazine biosynthetic locus from Pseudomonas aureofaciens 30-84. Mol. Plant-Microbe Interact. 5:330-339.

Rolfe, B. G., Gresshoff, P. M., and Shine, J. 1980. Rapid screening method for symbiotic mutants of Rhizobium leguminosarum biovar trifolii and white clover plants. Plant Sci. Lett. 19:277-284.

Rovira, A. D. 1956. A study of the development of the root surface microflora during the initial stages of plant growth. J. Appl. Bacteriol. 19:72-79.

Rovira, A. D., and Campbell, R. 1975. A scanning electron microscope study of interactions between micro-organisms and Gaeumannomyces graminis (Syn. Ophiobolus graminis) on wheat roots. Microb. Ecol. 3: 177-185.

Sacherer, P., Défago, G., and Haas, D. 1994. Extracellular protease and phospholipase $\mathrm{C}$ are controlled by the global regulatory gene gacA in the biocontrol strain Pseudomonas fluorescens CHA0. FEMS Microbiol. Lett. 116:155-160.

Salmond, G. P. C., Bycroft, B. W., Stewart, G. S. A. B., and Williams, P. 1995. The bacterial 'enigma': Cracking the code of cell-cell communication. Mol. Microbiol. 16:615-624.

Sambrook, J., Fritsch, E. F., and Maniatis, T. A. 1989. Molecular Cloning: A Laboratory Manual. 2nd ed. Cold Spring Harbor Laboratory, Cold Spring Harbor, NY.

Schippers, B., Bakker, A. W., and Bakker, P. A. H. M. 1987a. Interactions of deleterious and beneficial rhizosphere microorganisms and the effect of cropping practices. Annu. Rev. Phytopathol. 25:339-358.

Schippers, B., Lugtenberg, B. J. J., and Weisbeek, P. J. 1987b. Plant growth control by fluorescent pseudomonads. Pages 19-39 in: Innovative approaches to plant disease control. I. Chet, ed. John Wiley,
New York.

Schroth, M. N., and Hancock, J. G. 1981. Disease suppressive soil and root colonizing bacteria. Science 216:1376-1381.

Shanahan, P., O'Sullivan, D. J., Simpson, P., Glennon, J. D., and O'Gara, F. 1992. Isolation of 2,4-diacetylphloroglucinol from a fluorescent pseudomonad and investigation of physiological parameters influencing its production. Appl. Environ. Microbiol. 58:353-358.

Simons, M., van der Bij, A. J., Brand, I., de Weger, L. A., Wijffelman, C. A., and Lugtenberg, B. J. J. 1996. Gnotobiotic system for studying rhizosphere colonization by plant growth-promoting Pseudomonas bacteria. Mol. Plant-Microbe Interact. 9:600-607.

Smit, G., Logman, T. J. J., Boerrigter, M. E. T. I., Kijne, J. W., and Lugtenberg, B. J. J. 1989. Purification and partial characterization of the Rhizobium leguminosarum biovar viciae $\mathrm{Ca}^{2+}$-dependent adhesin, which mediates the first step in attachment of cells of the family Rhizobiaceae to plant root hair tips. J. Bacteriol. 171:4054-4062.

Thomashow, L. S., and Weller, D. M. 1988. Role of a phenazine antibiotic from Pseudomonas fluorescens in biological control of Gaeumannomyces graminis var. tritici. J. Bacteriol. 170:3499-3508.

Thomashow, L. S., and Weller, D. M. 1995. Current concepts in the use of introduced bacteria for biological disease control: Mechanisms and antifungal metabolites. Pages 187-235 in: Plant-Microbe Interactions. G. Stacey and N. T. Keen, eds. International Thomson Publishing, New York.

van Elsas, J. D., Trevors, J. T., and Starodub, M. E. 1988. Bacterial conjugation between pseudomonads in the rhizosphere of wheat. FEMS Microbiol. Lett. 53:299-306.

Weller, D. M. 1988. Biological control of soilborne plant pathogens in the rhizosphere with bacteria. Annu. Rev. Phytopathol. 26:379-407.

Zhang, L., Murphy, P. J., Kerr, A., and Tate, M. E. 1993. Agrobacterium conjugation and gene regulation by $\mathrm{N}$-acyl-L-homoserine lactones. Nature 362:446-448. 